\title{
THE EFFECT OF THE INFLAMMATORY REFLEX ON THE HEART
}

\author{
Aleksandar Kamenov ${ }^{1}$, Vladimir Stojiljkovići ${ }^{1}$ Saša Živić ${ }^{1}$, Marko Gmijovićc ${ }^{3}$, \\ Milan Lazarević ${ }^{1}$, Mladjan Golubović ${ }^{2}$, Dragan Milić ${ }^{1}$
}

\begin{abstract}
The native immune system is the main component of defense against pathogen, injury and trauma. Vagal fibers contain sensory and motor components controlling different functions such as heart frequency and digestion. There are lots of reasons this nervous based antiinflammatory pathway is useful, the cholinergic anti-inflammatory pathway, which is fast, separate and localized in tissue where the injury originated and can induce humoral systemic anti-inflammatory response which has a number of usefull effects on a number of heart diseases.
\end{abstract}

Acta Medica Medianae 2020;59(2):81-87.

Key words: heart disease, inflammatory reflex, vagal stimulation

\footnotetext{
${ }^{1}$ Department of Cardiac surgery, Clinical Center of Niš, Niš, Serbia

${ }^{2}$ Anesthesiology and Reanimation Center, Clinical Center of Niš, Niš, Serbia

${ }^{3}$ Digestive Surgery Clinic, Clinical Center of Niš, Niš, Serbia
}

Contact: Aleksandar Kamenov

48 Dr. Zoran Djindjić Blvd., Niš, Serbia

E-mail: kamenovcs@gmail.com

\section{Introduction}

Inflammation is a local, protective response to a microbial invasion or injury. This response must be harmonic and precisely regulated, therefore a response too strong or too weak will lead to morbidity and a shortened lifespan. Based on multiple scientific discoveries, the immune system is not viewed upon as autonomic, the vision of a selfregulating immune system is a long crushed paradigm. Experimental data show that the nervous system regulates immune functions and inflammation. The two-way communication between the brain and the immunological system is the underlying mechanism of inflammation control and immune system checkup. The discovery that the cholinergic neurons inhibit acute inflammation expands our knowledge and understanding about the modulation of immune response by the nervous system. The immune system is modulated by reflexes which adjust its center of balance which can be up or downregulated. The activity of the efferent vagal nerve maintains the homeostasis by limiting the pro-inflammatory response within the healthy and protective and nontoxic range.

Survival is impossible without the everwatching sentries against pathogen and injury. Native immune system is the autopilot on this craft. When facing assault it unwillingly creates a separate, localized inflammatory response to prevent any unnecessary damage (1). That response is mediated by macrophages, monocytes and other immune cells which release cytokines, interleukins and other mediators of inflammation (2). The volume of this response is of vital importance, for insufficient response leads to immunodeficiency which can lead to infection or cancer (2). On the other side of the spectre, an exaggerated response of TNF-a and other pro-inflammatory mediators leads to systemic inflammation implicating serious pathological complications such as sepsis, Chron's disease, RA, MS (2, 3 ), atherosclerosis, diabetes, Alzheimer, cerebral and myocardial ischemic diseases. If the inflammatory response spreads to the circulatory system, as is the case in septic shock, meningitis and heavy trauma, the response can be more lethal than the initial stimulus. Inflammation control is conveyed by two main mechanisms: native immune system's selfcontrol and immunoregulatory influence deriving from the brain (1).

Activated immune cells release anti-inflammatory cytokines, IL-10, IL-4, TGF- $\beta$ and soluble TNF receptors which play a counter-regulating role in inflammation (2). Hypothalamic-pituitary-adrenal axis, which controls the release of glucocorticoids is a neuroendocrine immunomodulatory mechanism and originates from the brain (4). The initial cerebral response to inflammation is mediated by autonomous nervous system pathway activation (1). The afferent vagal fibers send a quick signal to the brain to start sending immunomodulatory responses in 
the early phase of inflammation. Novel studies imply that the efferent vagal stimulus inhibits pro-inflammatory cytokine release and regulates inflammation, similar to the effects it has on the heart and gastrointestinal function (1). This efferent vagal function is noted as the cholinergic anti-inflammatory path (5). Homeostasis and health are reinstituted when inflammation is limited by anti-inflammatory responses which reoccur, are quick and reversible, localized and adaptive to changes in the sensory nervous signals and integrated in the nervous system. Recent discoveries have identified the basic nervous path which follows and regulates the antiinflammatory response in reflex. The inflammatory sensory signal activates the anti-inflammatory response which is both quick and involuntary and acts as a countermeasure to prevent the inflammatory mediators into the circulatory system. The nervous system integrates the inflammatory response, gathers information on the invasive events in the organism, mobilizes defense and creates memory to enhance survival (1). Both cholinergic anti-inflammatory mechanisms inhibiting the activation of macrophage and cytokine release and vagal stimulation, electrical and pharmacological, prevent inflammation and cytokine release, which is clinically relevant in treating diseases.

The native immune system is the main component of defense against pathogen, injury and trauma. The host recognizes molecular patterns related to the pathogen receptors like the Toll like receptors (TLR) (10), so in case of infection a lipopolysaccharide, part of the gram negative bacteria or an endotoxin activate the TLR4 receptors found on the macrophage, dendritic and other immune cells. Receptor interaction with the ligand induces intracellular pathways, leading to cytokine and other pro-inflammatory mediators' release (2). Tissue damage and trauma can, in absence of infection, activate the native immune response. Novel work show that the necrotic tissue damage leads to heatshock proteins release (HSP) and oxidized lipoprotein which in turn activate the immune cells via TLR $(2,8)$. Pro-inflammatory mediators induce vasodilatation, attract leukocyte and increase vascular permeability. The pro-inflammatory response is dampened by the anti-inflammatory mediators release (IL-10, IL-4...). Polyamine spermine released locally can suppress the pro-inflammatory response (9). Macrophage and dendritic cells, as antigen presenting cells, bind the native immune system with the lymphocyte $\mathrm{T}$ and $\mathrm{B}$ induction thereby laying foundation for creating specific immune response (2).

TNF-a is essential in the pro-inflammatory response, it is both necessary and sufficient as a mediator of local and systemic inflammation. The local rise in TNF-a causes the main clinical signs of inflammation (heat, swelling, pain and ruddiness). If released uncontrolled, it can lead from local to systemic and chronic inflammation leading to tissue damage and death. Many diseases (RA, ischemicreperfusion damage, sepsis) are flagged as inflammatory because of the crucial contribution of patho- logical complications of inflammation (2). With transition of local to systemic inflammation, the rise in TNF-a levels is toxic and mediates microvascular coagulation and capillary leak syndrome eventually leading to lethal shock (10). TNF sends its own and other proinflammatory mediators' synthesis into a spiral. Auto regulatory inflammation is normally characterized by a drop in TNF-a activity. Small quantities of TNF-a can contribute to the host defenses by limiting the spreading of pathogen into the circulation, enhancing coagulation around pathogen and stimulating the healing of damaged tissue. In a typical, successful inflammatory response, duration and quantity of of released TNF-a are limited, its useful and protective properties overrule and its actions are local.

\section{Vagal role in neuroimmunomodulation}

Vagal fibers contain sensory and motor components controlling different functions such as heart frequency and digestion. It was only later discovered that besides controlling these classical physiological functions it also prevents TNF-a, HMBG1, IL-1 and other pro-inflammatory cytokines from immune cells (1). Afferent vagal fibers play a role in immune signal transmission to the brain during inflammation and efferent fibers lead to inflammation suppression. Both types of fibers make the cerebrally integrated reflex mechanism controlling inflammation timing (1). Sympathetic immunoregulatory response is also a component of the efferent part of the inflammatory reflex.

\section{Afferent arch of the inflammatory reflex}

The central nervous system takes in its immune signals both through humoral and nervous pathways. Blalock originally suggested that the immune system works as a "sixth sense", discovering microbial invasion and producing molecules to translate this information to the brain (12). TNF and other immune mediators can get to the brain centers in the circumventricular region deprived of the bloodbrain barrier. And so, the dorsal vagal complex containing the sensory solitary tract nucleus, area postrema and dorsal vagal motor nucleus all respond to TNF-a blood level spikes and platos by changes in motor vagal activity. This humoral communication pathway between the immune and the nervous system is involved in the development of fever, anorexia and hypothalamic-pituitary responses to infection and injury, and also other behavioral disease manifestations. The most studied afferent pathway is the humoral one, through the hypothalamic-pituitary adrenal (HPA) axis, via circulating cytokines released from the peripheral leucocytes and then bonded to central cytokines receptors (13).

There is supposedly more than one possible way of signal conductance. One is active transport of cytokine through the BBB, the other being less likely through the cerebral vascular endothelia and thus inducing creation of secondary messengers such as prostaglandins and nitrous oxide. In vitro studies 
have shown IL-1 $\beta$, IL- 6 and TNF-a inducing changes in cerebral endothelial cells electric resistance. Alternatively, there is a possibility that soluble signal mediators, such as immune cytokines may get to the brain through the circumventricular organs with an incomplete BBB, enabling exchange of high molecular peptides between the blood and the brain. Experiments using highly neurotoxic mono-sodiumglutamate (MSG) resulting in lesions in the level of the hypothalamic arched nucleus (ARCN) (14, 15, 16). Lesions followed by a decrease in number of neurons and their degeneration in the area of ARCN leading to a derangement of the hypothalamic-pituitary-adrenal-thymus axis (HPATA) $(14,16)$ as well as hypothalamic-pituitary-thyroid axis (HPTA) (15). The neurons of the central ventral organs (CVO) are connected to the hypothalamic regions and nuclei of the neural stem, but the expression of the c-FOS protein is noted in the farther regions of the brain. During iv treatment with LPS a spike in number of cFOS protein positive cells in the main group of noradrenergic cells $(A 1, A 2, A 6)$ in the paraventricular (PVN) (17), supraoptic (SO) hypothalamic nuclei and in the limbic structures such as trough strial terminal nucleus, central amygdaloidal nucleus and the ventral septal area is registered. CVO contains many hormones, neurotransmitters and transmitter-like factors such as ACTH, acetylcholine, serotonin, dopamine as well as a high concentration of adequate receptors. This system of neurons can reach the farthest parts of the central nervous system including the strictures of the limbic frontal brain. It can be concluded that CVO plays a crucial role in translating cytokine signals into nervous activity. Neurons express type I receptors for IL-1 (IL1-RI), which is the main receptor for mediating IL-1 type cell response. During the bonding process between IL-1 and IL1-RI, the receptor forms a heterodimer with an accessory peptide IL-1R. This complex bonds with a primary myeloid differentiation response protein 88 (MYD88, an adapting TLR protein) and recruits signal proteins which in turn activate MAPK (mitogen activated protein kinase) and nuclear factor- $\mathrm{KB}$ (NF- $\mathrm{KB})(18)$. NF- $\mathrm{KB}$ activation in the neurons is entwined in management of proinflammatory gene transcription (19). Inside the paraventricular nucleus IL-1 stimulates neuron depolarization by activating non-selective COX dependent cationic conduction (20). This confirms the paradigm that the presence of IL-1 in the brain during injury or infection activates the nervous circuits to mediate a local and systemic pathophysiological response. Besides IL-1, which plays a central role in the inflammatory reflex sensory arch activation, other endogenic and exogenous factors when joined with inflammation can activate the inflammatory reflex. Infections molecular products activate macrophage, monocyte and other early response cells. All of these molecules interact with TLR and finally lead to NF-KB activation and an increased release of pro-inflammatory cytokines (21). Endogenous molecular products released form damaged cells during sterile injury or ischemia, even in absence of pathogen, include cytokines, HMGB1, HSP, hyaluronic fragments,
ATP, uric acid, heparin-sulphate and other molecular patterns related to injury (DAMP) (22).

Electrophysiological studies show that vagal stimulation can be achieved by TNF, other cytokines, mechanoreceptors, chemoreceptors, temperature and osmolality sensors which can all be activated inside the inflammation locus. Somatic sensory nervous signal inside the central nervous system is organized in a somatotropic fashion, like so that the sensory entry signal from a separate peripheral focal point is precisely localized in the ascending fibers and the brain.

\section{Cholinergic anti-inflammatory pathway - efferent inflammation reflex pathway}

Our understanding of basic inflammatory regulation mechanisms has evolved with the discovery of a nervous parasympathetic macrophage inhibition mechanism (5). It is named the "cholinergic anti-inflammatory pathway" for having acetylcholine as the primary parasympathetic neurotransmitter. It inhibits the release of TNF from LPS-treated macrophage (5). It should be underlined that acetylcholine only inhibits expression of TNF proteins in the macrophage, not the TNF induction of TNF iRNA, therefore, the inhibition is on a posttranscriptional level. Vagal stimulation significantly downregulates TNF, IL-1, IL-6 and IL-8 production, but not the anti-inflammatory cytokines production (IL-10, TGF$\beta)$. In vivo studies show that efferent cholinergic vagal neurons play a crucial role in controlling TNF levels and other immune responses. Macrophages that are exposed to acetylcholine get successfully deactivated. All vital organs are innervated by the vagal nerve, including those with a reticuloendothelial system (liver, lungs, spleen, kidneys and GIT) (23). Direct electric stimulation of the cholinergic efferent anti-inflammatory pathway protects the organism, significantly inhibits cytokine production by the innate immune cells in the mentioned organs and other tissues innervated by the vagal nerve ( 3 , 24) and can downregulate the TNF serum concentration in endotoxemia. Limiting the release of potentially toxic mediators produced by the innate immune cells, the cholinergic anti-inflammatory pathway protects the organism from organ damage and death during endotoxemia, sepsis, hemorrhagic shock, colitis, arthritis, ileus, pancreatitis and other syndromes with abnormal cytokines release. The level of protection achieved by electrical vagal stimulation depends mostly on the used voltage, and goes hand in hand with heart rhythm stabilization during the hypotensive phase induced by reperfusion. Vagotomy is followed by increased TNF levels in the serum in response to endotoxin treatment (5). It has a way of sensitizing an organism to lethal effects of endotoxins. Vagal nerve has a tonic effect of suppression of TNF release. The effect is an analog to the tonic inhibitory influence it has on the heart rhythm. With the lack of vagal stimulation on the heart, the frequency rises, also the pro-inflammatory molecules production increases as does the organ damage during times of endotoxin exposure 
(25). The net effect of the innate immune system to infection and injury is a reflection of the efferent inflammatory pathway reflex activity.

\section{Vagal inflammation suppression characteristics}

Efferent vagal stimulation is classically characterised by heart frequency lowering, induction of gastric motility, arteriolar dilatation and pupil narrowing. Inhibition of the inflammatory response can be added to this list. There are lots of reasons this nervous based anti-inflammatory pathway is useful. A diffuse anti-inflammatory network including glucocorticoids, anti-inflammatory cytokines and other humoral mediators is slow, divided, unintegrated and depends on the concentration gradients. On the other side of the spectrum is the cholinergic antiinflammatory pathway, which is fast, separate and localized in tissue where the injury originated and can induce humoral systemic anti-inflammatory response, this is possible because vagal activity can be translated to the medullar reticular formation, LC and the hypothalamus, leading to increased ACTH release from the frontal pituitary lobe.

Compared to the speed of the regular, biological inflammatory response (hours and days), the nervous signaling is closer to lightning. This regulatory property is useful in critical stages of disease. After a short refractory period, in the absence of the next nervous signal, appropriate cells can retrieve function.

\section{Immune homeostasis reflex control}

The inflammatory reflex affects the magnitude and the volume of native immune system's response. During the state of inactivity, the inflammatory reflex contributes to the balance of the immune response on the molecular products of infection, injury or ischemia. Vagal response maintains homeostasis by limiting the pro-inflammatory response in the optimal range and the damaged tissue in a state of mild stimulation. Patients with inflammatory diseases have functionally elevated states of balance during inactivity, producing high levels of pro-inflammatory mediators and a momentarily reduced heart frequency variability rate, which is an index of educed vagal activity. Healthy individuals have a lowered state of equilibrium of that comes with an elevated index of vagal activity and a lowered proinflammatory cytokines release response. Physical exercise, controlled breathing, fish oil consumption in daily diet and relaxation have a stimulating effect on vagal activity and suppress pro-inflammatory cytokine release (29).

\section{Therapeutic implications}

A question arises, does activating the inflammatory reflex cause immunosuppression? Experiments on animal models show that targeted therapy that boosts the inflammatory reflex activity actually normalizes the native immune response without its discontinuance or immunosuppression onset. Electric or pharmacological stimulation of the inflammatory reflex sets the equilibrium plane inside the protective range instead of completely inhibiting innate immune response. Electric vagal stimulation or a7nACh agonist administration reduces pro-inflammatory cytokine volume production by $50-75 \%$ without eliminating their activity $(24,26)$.

Besides electrically, it is possible to achieve vagal stimulation pharmacologically, small molecules can activate the inflammatory reflex by starting signals in the proximal components of the CNS. One such molecule is the CNI-1493, a tetravalent guanyl hydrazone, described as an inhibitor of macrophage activation and TNF release. This substance inhibits TNF synthesis and inflammatory response both locally and systemically in animal model, and reduces Crohn's disease clinical symptoms significantly in small studies (29).

Specific anti-inflammatory response is achieved by acetylsalicylic acid administration, but not with dexamethasone. Amiodarone, an antiarrhythmic medication used to treat and prevent a number of types of irregular heartbeats, including ventricular tachycardia, ventricular fibrillation, and wide complex tachycardia, as well as atrial fibrillation and paroxysmal supraventricular tachycardia, is identified as a TNF synthesis inhibitor inside the monocytes in vitro, and also a potent vagal activity stimulator (30). Systemic administration of nonsteroidal anti-inflammatory medicines, aspirin, indomethacin and ibuprofen increases vagal stimulation.

It is not noted that this pathway's activation causes immunosuppression because maximal suppression reduces pro-inflammatory cytokine level from toxic to normal. This concept is deemed to be a possible treatment for many inflammatory diseases, including infections, ischemia-reperfusion syndrome and injury.

There are a number of studies, both with on animal model and in human subjects with heart failure that have shown promising results.

Effectiveness of chronic electrical vagal stimulation has been assessed in three animal models of heart failure. Rats subjected to a large anterior myocardial infarction (MI) leading to heart failure were randomized to vagal and shamstimulated groups 14 days post-MI. The vagus was stimulated for 10 $\mathrm{sec} / \mathrm{min}$, with an intensity adjusted to reduce heart rate by $20-30 \mathrm{bpm}(5-10 \%)$. Rats randomized to vagal stimulation showed significant improvement in left ventricular (LV) hemodynamics and decreased mortality from $50 \%$ to $14 \%$ at 140 days (30).

In an established canine model of intracoronary microembolization-induced heart failure, vagal stimulation significantly improved LV function compared to sham operated animals (31).

In the same animal model, therapy with vagus nerve electrical stimulation combined with beta-blockade improved left ventricular systolic function beyond that seen with beta-blockade alone. More recently, the effects of chronic vagal stimulation in a canine rapid pacing model of heart failure (HF) were presented (32). 
These dogs were subjected to 8 weeks of high-rate ventricular pacing with concomitant VNS in the active group and no stimulation in the control group. At the end of the 12-week study period, vagally stimulated animals had significantly lower LV end-diastolic and end-systolic volumes and higher LV ejection fraction. This result was obtained in the absence of any heart rate effect provided by vagal stimulation since both groups were subjected to the same constant ventricular pacing. The effect of VNS on chronic pressure-overload hypertrophy, which is similar to heart failure with preserved ejection fraction (HFpEF), was evaluated in a guinea pig study (33).

Chronic low-amplitude VNS abolished adverse LV remodeling (end-systolic and end-diastolic volume changes) induced by chronic aortic constriction.
1. Tracey K. The inflammatory reflex. Nature 2002; 420:853-9. [CrossRef] [PubMed]

2. Nathan C. Points of control in inflammation. Nature 2002;420:846-52. [CrossRef] [PubMed]

3. Wang $\mathrm{H}$, Yang $\mathrm{H}$, Tracey $\mathrm{KJ}$. Extracellular role of HMGB1 in inflammationand sepsis. J Intern Med 2004; 255:320-31. [CrossRef] [PubMed]

4. Webster JI, Teonelli L, Sternberg EM. Neuroendocrine regulation of immunity. Annu Rev Immunol 2002; 20:125-63. [CrossRef] [PubMed]

5. Borovikova LV, Ivanova $S$, Zhang $M$, Yang $H$, Botchkina GI, Watkins LR, et al. Vagus nerve stimulation attenuates the systemic inflammatory response to endotoxin. Nature $2000 ; 405: 458-61$.

[CrossRef] [PubMed]

6. Wang $\mathrm{H}$. Nicotinic acetylcholine receptor a7 subunit is an essential regulator of imflammation. Nature 2003; 421:384-8. [CrossRef] [PubMed]

7. Aderem A, Ulevitch RJ. Toll-like receptors in the induction of innate immune response. Nature 2000; 406:782-7. [CrossRef] [PubMed]

8. Seaffidi $P$, Misteli T, Bianchi ME. Release of chromatin protein HMGB1 by necrotic cells triggers inflamation. Nature 2002;418:191-5. [CrossRef] [PubMed]

9. Zhang $M$, Wang $H$, Tracey KJ. Regulation of macrophage activation and inflammation by spermine: a new chapter in an old story. Crit Care Med 2000;28 (Suppl):60-6. [CrossRef] [PubMed]

10. Cohen J. The immunopathogenesis of sepsis. Nature 2002;420:885-91. [CrossRef] [PubMed]
11. Blalock JE, Smith EM. Conceptual development of the immune system as a sixt sense. Brain Behav Immun 2007;21:23-33. [CrossRef] [PubMed]

12. Da Salva JA. Sex hormones and glucocorticoids: interactions with the immune system. Ann N Y Acid Sci 1999;876:102-17. [CrossRef] [PubMed]

13. Cekić $S$, Filipović $M$, Nešić $M$, Dimitrijević $O$, Pavlović $M$, Branković $S$, et al. Long-term effect of neonatal monosodium glutamate (MSG) treatment on hypothalamus pituitary-adrenal-thymus axis of rats. Virchows Archiv 2003;443(3):257. [PubMed]

14. Cekić $S$, Filipović $M$, Jović $Z$, Nešić $M$, Pešić $G$, Ćirić $M$, et at. Histopathological changes at the hypothalamic nucleus arcuatus and thyroid level in rats treated with monosodium glutamate. Acta Facultatis Medicae Naissensis 2004;21(2): 89-94.

15. Cekić S, Filipović M, Pavlović V, Ćirić $M$, Nešić $M$, Jović, et al. Histopathologic changes at the hypothalamic nucleus arcuatus adrenal and thymus in rats treated with monosodium glutamate. Acta Medica Medianae 2005;44(3):35-42.

16. Rivest S, Lacroix S, Valihres I, Nadeau S. How the blood talks to the brain parenschyma and the paraventricular nucleus of the hypothalamus during systemic inflammatory and infectious stimuli. Proc Soc Exp Biol Med 2000;223:22-38. [CrossRef] [PubMed]

17. Davis CN. MyD88-dependent and -independent signaling by IL- 1 neurons probed by bifunctional Toll/IL-1 receptor domain/BB-loop mimetics. Proc Natl Acad Sci USA 2006;103:2953-8. [CrossRef] [PubMed] 
18. Mattson MP. NF-KB in the survival and plasticity of neurons. Neurochem Res 2005;30:883-93. [CrossRef] [PubMed]

19. Ferri CC, Yulli EA, Ferguson AV. Interleukin-1 $\beta$ depolarizesmagnocellular neurons in the paraventricular nucleus of the hypothalamus through prostaglandin-mediated activation of a non selective cationic conductance. Regul Pept 2005;129:63-71. [CrossRef] [PubMed]

20. Medzihtov R. Origin and physiological roles of inflamemation. Nature 2008;428-35. [CrossRef] [PubMed]

21. Blanchi ME. DAMPs, PAMPs and alarmins. All we need to know about danger. J Leukoc Biol 2007;81:1-5. [CrossRef] [PubMed]

22. Bellinger $\mathrm{DL}$, Lorton $\mathrm{D}$, Lubahn $\mathrm{C}$ and Felten $\mathrm{DL}$ editors. In Psychoneuroimmunology. Academic San Diego 2001;55-112.

23. Houston JM. Splenectomy inactivates the cholynergic antiinflamatory pathway during lethal endotoxemia and polymicrobial sepsis. J Exp Med 2006;203:16238. [CrossRef] [PubMed]

24. Chia JE, Blennerhasset $P$, Collins SM. Impaired parasymphatetic function increases susceptability to inflammatory bowel disease in a mouse model of depression. J Clin Invest 2008;118:2209-18. [CrossRef] [PubMed]

25. Parrish WR. Modulation of TNF release by choline requires a7 subunit nicotinic acetylcholine receptormediated signaling. Mol Med 2008;14:567-74. [CrossRef] [PubMed]

26. Razani-Boroujerdi. T-cells ewpress a7-nicotinic acetylcholine receptor subunits that require a functional TCR and leucocyte-specific protein tyrosine kinase for nicotine-induced $\mathrm{Ca} 2+$ response. J Immunol 2007; 179:2889-98. [CrossRef] [PubMed]

27. Bernik TR, Friedman SG, Ochani M, DiRaimo R, Ulloa $L$, Yang $H$, et al. Pharmacological stimulation of the cholinergic antiinflammatory pathway. J Exp Med 2002;195:781-8. [CrossRef] [PubMed]

28. Hommes D, Van den Blink B, Plasse T, Bartelsman J, $\mathrm{Xu} \mathrm{C}$, Macpherson B, et al. Inhibition of stressactivated MAP kinases induces clinical improvement in moderate to severe Crohn's disease. Gastroenterology 2002;122:7-14. [CrossRef] [PubMed]

29. Dias DS, Gnecchi-Ruscone T, Lavelli B, Bellina V, Manzella D, Porta A, et al. Opposite effects of iv amiodarone on cardiovascular vagal and sympathetic efferent activities in rats. Am J Physiol Regul Integr Comp Physiol 2002;283:543-548. [CrossRef] [PubMed]

30. Li M, Zheng C, Sato T, Kawada T, Sugimachi M and Sunagawa K. Vagal nerve stimulation markedly improves long-term survival after chronic heart failure in rats. Circulation. 2004;109:120-4.

[CrossRef] [PubMed]

31. Sabbah HN, Rastogi S, Mishra S, Gupta RC, Ilsar I, Imai $\mathrm{M}$, et al. Cohen $\mathrm{U}$, BenDavid $\mathrm{T}$ and Ben- Ezra O. Long-term therapy with neuroselective electric vagus nerve stimulation improves LV function and attenuates global LV remodelling in dogs with chronic heart failure. Eur ] Heart Fail 2005;166. [CrossRef]

32. Zhang Y, Popovic ZB, Bibevski S, Fakhry I, Sica Da, Van Wagoner DR, et al. Chronic vagus nerve stimulation improves autonomic control and attenuates systemic inflammation and heart failure progression in a canine high-rate pacing model. Circulation Heart failure. 2009;2:692-29. [CrossRef] [PubMed]

33. Beaumont E, Southerland E, Hardwick J, Ryan S, KenKnight B, Ardell J. Chronic autonomic regulation therapy mitigates adverse remodeling induced by pressure overload in the guinea pig heart. J Am Coll Cardiol 2014;63. [CrossRef] 


\title{
EFEKAT ANTIINFLAMATORNOG REFLEKSA NA SRCE
}

\author{
Aleksandar Kamenov ${ }^{1}$, Vladimir Stojiljkovići ${ }^{1}$ Saša Živić ${ }^{1}$, Marko Gmijovićn \\ Milan Lazarević ${ }^{1}$, Mlađan Golubović2 ${ }^{2}$ Dragan Milić ${ }^{1}$
}

${ }^{1}$ Klinika za kardiohirurgiju, Klinički Centar Niš, Niš, Srbija

${ }^{2}$ Klinika za anesteziju i reanimaciju, Klinički centar Niš, Niš, Srbija

${ }^{3}$ Klinika za digestivnu hirurgiju, Klinički centar Niš, Niš, Srbija

Kontakt: Aleksandar Kamenov

Bulevar dr. Zorana Đinđića 48, 18000 Niš, Srbija

E-mail: kamenovcs@gmail.com

Nativni imuni sistem je glavna komponenta odbrane od patogena, povreda i trauma. Vagalna vlakna sadrže senzorne i motorne komponente, koje kontrolišu funkcije, kao što su srčana frekvenca i varenje. Ovaj antiinflamatorni put bitan je iz više razloga - brz je, funkcioniše separatno od imunog sistema i lokalizovan je na inicijalno povređeno tkivo i može indukovati humoralni sistemski antiinflamatorni odgovor, sa više pozitivnih efekata po srce.

Acta Medica Medianae 2020;59(2):81-87.

Ključne reči: srčane bolesti, upalni refleks, vagalna stimulacija 